\title{
Securities and Exchange Commission of Pakistan's regulations for Sharī'ah Screening of Stocks and Shares: Sharī'ah based Evaluation
}

\author{
Anees Tahir * \\ Advocate for Business Law \\ LLM from Faculty of Sharī'ah and Law, International University, Islamabad, Pakistan \\ Candidate for Ph.D Law IIUM, Malaysia
}

\section{Keywords \\ Islamic Stocks Index \\ Core Business \\ Financial Ratios for \\ Stocks Screening \\ Screening Criteria \\ Purification Criteria \\ Qawā' id Al-Fiqhīyah}

Received: $28-$ Sep-19

Accepted: $15-$ Dec-19

\begin{abstract}
In 2016, the Securities and Exchange Commission of Pakistan (SECP) launched All Shares Islamic Index in collaboration with Pakistan Stock Exchange to measure the performance of Shari' 'ah compliant companies. This index is made up of over 250 companies. The stocks and shares that meet the Shari' 'ah Screening criteria are included in the All Shares Islamic Index. As part of the selection process, each company's financial report is reviewed and their Shari' ${ }^{-}$ah compliance status checked against technical filters and Sharī'ah screening criteria prescribed by the Securities and Exchange Commission Pakistan. The criterion for All Shares Islamic Index is developed by SECP to examine whether a particular stock conforms with Shari' 'ah or not. This article aims to analyze the screening criteria for companies developed by the SECP. According to All Shares Islamic Index, a company that borrows with interest up to $37 \%$ is considered as a Sharī'ah-compliant company. Similarly, a company that invests on interest up to $33 \%$ is also considerd as Sharī'ah compliant. The author argues that the criterion for lending and borrowing by the companies does not conform to Sharī'ah since Sharī'ah does not allow dealing

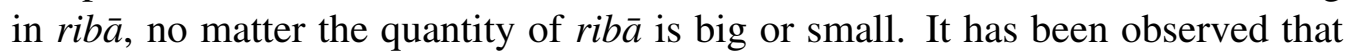
a comprehensive legal, regulatory, and operational framework does not exist for Shar'`ah-compliant dealing in shares/securities in the stock exchange. Although the SECP has attempted to provide a benchmark and a criterion for Sharī'ah-compliant trading, but that criterion itself suffers from flaws and involves Sharī'ah issues. In order to develop an Islamic capital market, it is imperative to amend the current legal and operational framework and the screening criterion needs to be revisited to make it a genuinely Sharī'ah-compliant screening criterion.
\end{abstract}

KAUJIE Classification: L2, L24, L4

JEL Classification: G21, G24, Z12

(C) 2019 JIBM. All rights reserved.

\footnotetext{
*Corresponding author: Anees Tahir

†Email: aneestahir6@gmail.com
} 


\section{INTRODUCTION}

In the Stock market, hundreds and thousands of securities are traded. The stock market provides the investors to earn profit through this buying and selling. Many of the securities and stocks do not meet the requirement of a lawful business from Sharīah point of view. The investee companies many times are involved in interest-based borrowing and lending. Given this situation, many faith sensitive investors abstain from investing in shares of companies which do not fulfill the requirement and conditions of Sharī'ah for haläl business. Considering this situation, many Islamic finance experts and Islamic finance regulatory bodies have attempted to devise criteria based on which a company or a stock could be determined whether it is Sharīah-compliant or not.

In Pakistan, the Sharī'ah scholars and finance experts of Meezan Bank and Al-Meezan Investment Management Limited (MIM) developed a mechanism for screening shares and stocks from the Shari' ${ }^{-}$ah perspective. This screening criterion was later adopted by the Securities and Exchange Commission of Pakistan in 2016 and issued it as Sharī'ah screening criteria for companies included in the "All Shares Islamic Index." According to information available on the website of SECP, around 280 Shari' ah-compliant companies are on the index. Thus, SECP helps the faith sensitive investors to find avenues for haläl earning through investment in the stocks and equities of such companies. In 2018, the SECP issued "Shari' ah Governance Regulations, 2018," which made substantial changes in the Shari' 'ah screening criteria applicable for "All Shares Islamic Index." The regulations provide that a company desirous to operate as Sharī'ah-complaint company, has to obtain first Sharī'ah certification from the SECP (Government of Pakistan \& Securities and Exchange Commission of Pakistan, 2018). Stock Exchange has been authorized to conduct Sharī'ah screening of companies on half-yearly basis and to declare whether a particular company has remained Shari' ah compliant during that period or not. Thus, the list of Shari'ah-compliant companies is updated every six months. For this purpose, financial reports of a company are thoroughly reviewed by the research analysts of Stock Exchange. It is worth mentioning that the tax laws of the country give a certain rebate in tax to Sharí'ah-compliant companies, the relaxation that is not available to Sharī'ah non-complaint companies.

This article intends to evaluate from Sharí'ah's perspective the Sharī'ah Screening Criterion of the Securities and Exchange Commission of Pakistan, for the companies inncluded in the "All Shares Islamic Index, 2016".

\section{All Shares Islamic Index}

As stated earlier, 'All Shares Islamic Index', 2016 is based on certain criteria for screening of companies that could be selected for Sharī'ah compliant investments. The criteria contains certain Sharī'ah norms against which the Sharī'ah compliance of a company is judged. The companies and stocks included in All Share Islamic Index are those companies which meet the eligibility criteria of a Sharī'ah-compliant company. The Shari 'ah screening criteria prescribed by the SECP for the companies on "All Shares Islamic Index" is as under: 
Screening criteria \# 1: Business of the investee company: The criteria provide that the core business of the investee company should be halāl and permissible. It should not be inconsistent with the Sharī'ah principles for a valid business. As such, the shares of the company which is engaged in some unlawful and prohibited activity such as gambling, conventional insurance, conventional banking, dealing in pork, wine or Tobacco, etc. are unlawful, and their trading is prohibited. In the same way, the companies which carry out unethical business such as the industry which promotes obscenity and pornography, are also treated unlawful, and the trading of their shares is prohibited.

Screening criteria \# 2: Interest bearing debt to total assets not to exceed 37\%: The InterestBased Debt ratio to total assets should not exceed $37 \%$ of the total assets. The word debt in these criteria covers debentures, bonds, commercial papers, Term finance certificates, finance lease, etc. The rationale for tolerating interest-based debts up to $37 \%$ is that an ordinary and minority shareholder does not have any role in the decisions of the company for interest-based borrowing and lending. He does not have prior knowledge of this practice while subscribing to the share of a company that is involved in interest-bearing lending or borrowing. Now if he raises his voice against this practice in the annual general meeting he is absolved of his responsibility.

Screening criteria \# 3: Non-compliant investments to total assets not to exceed 33\%: Criteria No. 3 provides that if a company under certain circumstances makes investment of its surplus funds in conventional banks and mutual funds or buys T-bills, Commercial papers, or futures contracts, then such unlawful investments will be tolerated only up to the extent of $33 \%$. If this investment exceeds $33 \%$ then such a company will be considered as a Sharī'ah non-compliant company.

Screening criteria \# 4: Non-complaint income to total revenue not to exceed 5\%: The screening criteria No. 4 indicates that the income derived from unlawful investment and Shar' 'ah non-compliant business should be less than $5 \%$ of total income of the company. For example, the company has invested its funds in conventional banks or conventional insurance companies and has received insurance claim, or it has invested in financial derivatives, or it has received some income from the sale of addictive drugs, etc. then such company will be considered Sharī ah-compliant only when the illegitimate income from the above sources remains less than $5 \%$ of the total income of company.

Screening criteria \# 5: Illiquid assets to total assets must be greater than 25\%: Illiquid assets ratio to total assets of the company should not be less than $25 \%$. Illiquid assets mean equipment, plants, property, land, raw material, etc.

Screening criteria \# 6: Net liquid assets/share vs. market price/share: Market Price per share should be at least equal to or greater than net liquid assets per share. 


\section{Sharī'ah Analysis of the Screening Criteria}

When a person buys shares of a company, he becomes a partner in the business of that company. He owns the assets of the company in proportion to his share. If the company is involved in some unlawful and prohibited business, he is considered a partner in that unlawful business. If the company earns some profit from unlawful business, such earning is harām for a shareholder. In the present day financial system, every company raises funds for its business either through floating of shares or through arranging to borrow from banks. The companies, which need funds, generally borrow money against fixed interest for their business or working capital needs. Now when a person buys shares of such a company, he becomes part of that interest-based borrowing. Similarly, the companies may deposit their surplus funds in conventional banks, and every shareholder is participating in this riba based business. Another issue that needs investigation from Shari'‘ah's point of view is that each company has tangible assets, cash, debts and receivable. If the company's shares are at initial stage and represent only cash, then to sell a share at a price different from its face value amounts to violation of rules of bay ${ }^{\text {al-sarf }}{ }^{1}$. The question is: can an investor invest in shares of a company whose assets, in addition to fixed assets, are in form of cash, debit, and receivables? The Sharī'ah screening criteria provided by the Securities and Exchange Commission of Pakistan has attempted to address these issues. There are, however, many Shar'̄'ah problems in the criteria. The Sharī'ah justification given by the Sharī'ah scholars in favour of these criteria needs to be examined from Shari' ${ }^{-}$ah perspective. In the following, the criteria for selection of companies to be included in "All Shares Index" of the SECP have been evaluated from Shar̄̄'ah point of view.

The lawfulness of core business of company: It is a requirement of Shari' ah that the subject matter of transaction should not be a thing which has been prohibited in Sharí'ah. Islam urges a Muslim to eat what is permissible ( $h a l \bar{a} l$ ) and pure (tayyab). Islam also emphasizes on haläl business and earnings. In a hadìth, Holy Prophet (PBUH) has said that Allah does not respond to the prayer of a person whose earning is harām (Muslim, 2000). On this basis, the SECP's criteria require that the business of investee company should be permissible. It does not allow investment in the companies which are engaged in unlawful business such as insurance companies, conventional banks, alcohol producing /distributing companies, pork-related industry, casino, pornography industries, etc. The screening criteria emphasizes that the core business should be permissible in Sharī'ah. This implies that if the core business of the company is permissible from Shari'ah's perspective, but some of its activities are unlawful, then such a company may be tolerated for investment provided unlawful portion of its earnings does not exceed 5\% of its total income as provided in screen or filter no. 5 . It may include companies involved partly in impermissible business, i.e., hotels or airlines, which may serve alcoholic drinks as part of their operations, besides their core business. AAOIFI's Sharī'ah Standard No. 21 Financial Papers (Shares and Bonds) states:

"That the amount of income generated from prohibited component does not exceed $5 \%$ of the total income of the corporation irrespective of the income being generated by undertaking a

${ }^{1}$ Sarf refers to exchange of gold for gold or gold for silver. It also applies to exchange of money for money. 
prohibited activity, by ownership a prohibited asset or in some other way. If a source income is not adequately disclosed, then more efforts to be exerted for identification therefore, giving due care and caution in this respect (Accounting and Auditing Organization for Islamic Financial Institutions, 2015).

The Sharī ${ }^{-}$ah Standard provides Sharī' ah basis for the above criteria. According to this criteria if the core business of a company is permissible, but it is partly engaged in some unlawful activity from which it earns a small portion of income then such company is Sharī'ah-compliant based on the juristic concept of "Separation of bargain" (tafrīq al-șafqah")

Such harām portion has to be purified through giving it to the poor and needy people. According to the above criteria, investor is not allowed to use such harām part of earning and has to be doled out to get rid of illegitimate income and to help the poor people.

Interest bearing lending and borrowing: SECP's criteria provide that if a company borrows funds from financial institutions against interest or if it lends with interest, then such company will be treated a Shari'ah non-compliant company only when it crosses the bench mark set by the SECP which is $37 \%$ and $33 \%$ respectively. The matter to be analysed is: is a company whose core business is hala $\mathrm{a}$, but that is involved in interest-based borrowing and lending, can be considered as a Shar'̄ah-compliant company? Is investment in such companies permissible in the perspective of severe prohibition of interest?

The contemporary Sharī'ah scholars have a difference of opinion on the issue. One group of scholars allows investment in such companies, and the other group does not allow it. In the following, these opinions are discussed:

Opinion no 1: The investment in such companies that are involved in prohibited activities to certain extent is permissible with certain restrictions. Those who maintain this view include several Sharī'ah scholars and fiqh councils such as Sh. Muhammad Taqi Usmani, Dr. Nazih Hammad, Shaikh Muhammad ibn Othaimin, the Sharī ah Board of Accounting and Auditing Organization for Islamic Financial Institutions, Sharí' ah Board of Islamic Bank of Jordan (Al-Umrani, 2006)

Their opinion is based on the following arguments.

1- The Maxim: "General need assumes the status of necessity" (Zarqa, 1983, p. 155) The company has become a need of people. The people and intermediary institutions need avenues to invest their savings, and the Stock exchange provides this opportunity to them. If this door is closed, they will be in severe hardship and will have no option other than to deposit their savings in conventional banks.

AAOIFI's Sharī'ah standards on Financial Papers explain their argument in the following words:

"The basis for exempting trading in the shares of these corporations, whose primary activity is permissible; however, they deposit amounts and borrow on interest basis, is the application

\footnotetext{
${ }^{2}$ tafrìq al-safqah means sale of two things in single transaction, one permissible and another impermissible with one price. If the price of permissible can be distinguished from that of impermissible, such sale is allowed to the extent of permissible thing.
} 
of the rule of removal of hardship and acknowledging of general practice, widespread practice the acknowledge principle of predominance..." (Accounting and Auditing Organization for Islamic Financial Institutions, 2015).

Islamic law acknowledges that sometimes a public need becomes necessary, which calls for relaxation. It allows departure from the original law, in case of hạjah ' $\bar{a} m m a h$.

Examples of needs which are advanced to the degree of necessity are permissions of the contracts of salam, (advance purchase of goods with future delivery), istisna $\bar{a}^{\text {' (contract of }}$ manufacturing on order), bay ${ }^{6}$ bil-waf $\bar{a}$ (sale with right of redemption) ${ }^{3}$, loan etc in Hanafi school of law. A pre dominant view in Hanafi school is that salam is exception to the general rule that prohibits the sale of a non-existing thing. The salam transaction is effected on a commodity that does not exist at the time of contract. It. However, has been allowed by the Holy Prophet (PBUH) keeping in view the general need (hajjah 'āmmah). The same applies to the contract of istișna $\bar{a}^{6}$ which is a contract on non-existing subject matter. In Hanafi law these transactions are established by istihsān (Juristic preference). Imam ibn al-Qayyim, however, does not consider these contracts exception to the general rule or based on istihsān as the same are established by the clear texts. According to the Hanafi jurists bay bil-waf $\bar{a}$ is not a real sale but it is a mortgage. In bay 'bil-waf $\bar{a}$ the seller of property is in fact a borrower who has mortgaged his property with the purchaser (the lender) and the lender takes benefit of mortgaged property. Applying the rule that prohibits benefit from mortgaged property by the lender, it should have been prohibited but the Hanafi jurists allow bay 'bil-waf $\bar{a}$ keeping in view the general need of the people who cannot get loan for their needs except with the arrangement of bay' bil-waf $\bar{a}$. Similarly, loan (qard) is basically an exchange of money for money, which is required to be like for like and hand to hand. But since loan is a general need, so it has been allowed with time delay without any addition, of course. It is pertinent to note that other Muslim jurists does not subscribe to this view. In their view point, salam, loan etc. are established by the clear texts from the Qur'ān and Sunnah so the question of exception to general rule does not arise (Saeed ur Rehman, Hanafi Nazria e Istihsāan aur Asri Masail in Mansoori \& Abro, 2006).

2- Maxim: "A thing (act) which cannot be avoided, should be tolerated" (Nadawi, 2000, p. 472) The maxim provides that an act which is in itself not desirable, but it cannot be avoided, may be tolerated. Based on this maxim, the Sharī'ah scholars argue that dealing with the companies cannot be avoided today. These companies need capital to expand their business. One way to raise funds is by borrowing and lending.

3- Maxim: "Majority inherits the rule of the whole thing" (Nadawi, 2000, p. 463);

Principle: "A Small prohibited portion mixed with a major permissible part, does not render the whole unlawful."

The argument based on the above principles is that if the core business of a company is

\footnotetext{
${ }^{3}$ Bay bil-waf $\bar{a}$ is a sale of certain property by a prospective borrower to the lender to obtain loan against this property. He sells, for instance a house for ten lac rupees on the condition that whenever he has money he will give it to the purchaser i.e., the lender and buy his house back at the same price. It is designated as bay bil-waf $\bar{a}$ because the lender, the purchaser abides by his commitment to sell it back to the borrower, the seller. According to later Hanafi jurists, this is allowed on basis of istihsān and public need. The apparent issue in this sale is that the lender benefits from the mortgaged property, which amounts to rib $\bar{a}$.
} 
permissible, a small prohibited part mixed with it does not make the whole business unlawful. Furthermore, their argument is based on the views of prominent Muslim jurists. For example, Imam Ibn Tamiyyah says: "If harām is mixed with haläl, it is either harām in itself like carrion or harām for some external attribute. In the first case, if halāl is mixed with it, the whole will be regarded as unlawful. However, if it is of second type, such as he has acquired a thing through riba or gambling transaction and this money from rib $\bar{a}$ is mixed with his halāl money, all will not be treated harām. The harām portion will be estimated and will be separated and disposed of accordingly" (Ibn Taymiyyah, 2004).

4- Rule of Ownership of Borrowed Amount

Another argument provided by Sh, Muhammad Taqi Usmani in favor of investment in the above companies is that the borrower becomes the lawful owner of the amount, and the things procured in exchange for that money, are not harām. Thus, sinful borrowing does not render the whole business of the company, haräm. According to Sh. Muhammad Taqi Usmani, the borrowed money moves in to the risk and liability of borrower. Because of this risk and liability, he is entitled to its reward. So, he can invest it in the trading of shares, and any income from it, in the form of capital gain or dividends is permissible for him (Usmani, 1996).

He, however, suggests that the shareholder should record his protest in AGM against the interest-based borrowing and lending, and once he has raised his voice, he is absolved of his responsibility.

5- Status of a Shareholder in Joint Stock Company

The Sharī'ah scholars favoring investment in the above companies argue that the position of a shareholder in any Joint Stock Company is different from a partner in any partnership. The partners are agent. In partnership decisions are taken unanimously. Thus, they are all equally responsible for all activities of the partnership. This is not the case in Joint Stock Company where decisions are made by the majority, or by the directors entrusted with the job of management. Thus, it is not fair that a minority shareholder is held responsible for the wrong decision of Directors or the majority shareholders.

6- Process of Purification of haräm Income

Some Shari' 'ah scholars of the above category have suggested that in the case of interestbased lending, the whole amount of riba $\bar{a}$, should be disposed of by giving it to the needy and the poor. In case of interest-based borrowing, they suggest that the investor should purify that income, by disposing of the amount of riba received.

In a symposium of Al-Barkah, fatwá No. 12, it was held that

"If the value of a share of a company which sometimes carried interest-bearing borrowing has risen, due to interest-based loan and performance of company, any value addition in the company owing to injection of interest-bearing loan/capital should be proportionately donated in charity." Commenting on the fatwá, Abu Ghuddah (2002), a renowned scholar of Islamic finance, held the view that such charity is only a recommended act, not obligatory on the investee company. 
Opinion no. 2: Investment in the companies which are involved in interest-based borrowing and lending is impermissible.

Fiqh council of World Muslim League, Makkah, International Fiqh Academy, Council of Fatwá and Research, Kingdom of Saudi Arabia (Fatwá no. 7468). Sharī'ah Board of Kuwait Finance House (Sharī'ah Rulings on Economic Matters, Kuwait Finance House, Fatwá No. 532), Sharī'ah Board of Dubai Islamic Bank, (Fatwá No. 49), Sharī'ah Supervisory Board of Islamic Bank of Sudan (Fatwá No. 16) and a large number of renowned religious scholars like Sheikh Abdul Aziz ibn Baz, Shaikh Salih Fouzan, Allamah Yusuf al-Qaradawi, Dr. Ali Salus, Shaikh Abdullah Ibn Bai, etc. hold this view (Al-Umrani, 2006).

In one of its Sharī'ah verdicts, Fiqh Academy of Rabitah al-Alam al-Islami maintained that

"It is not lawful for a Muslim to buy shares of companies or banks which partly deal in rib $\bar{a}$ when the buyer is fully aware of the fact. The reason for its prohibition is that the

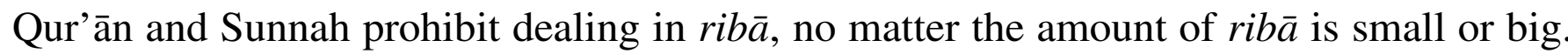
To purchase shares of the company which deals in rib $\bar{a}$ knowingly, are to take part in rib $\bar{a}$ based activity because the management of company while lending or borrowing money with interest, in fact, acts as an agent of shareholders".

The Permanent Committee for Academic Research and Fatwá, (Fatwá No. 7468) KSA ruled:

"It is not permissible to subscribe shares of companies which deposit their surplus amount in the interest-bearing account when the purchaser knows about it. It is a kind of cooperation in the act of sin and disobedience". It further provides: "Placement of funds of these companies in conventional banks is impermissible likewise, to be a shareholder in companies that deal in riba, is unlawful, even if such company was not originally founded for $r i b \bar{a}$ activity."

The arguments of this class of Sharī'ah scholars/committees are as follows:

1- Cooperation in Sin and Disobedience

These scholars argue that to subscribe share of a company which is included in interest borrowing and lending is a sort of cooperation and assistance in the act of sin and disobedience.

2- Subscription in Stocks is not a General Need

It is not correct that investment in such shares is permissible on the ground of hājah, because investing in stocks is not a general and public need. Furthermore, a ban on the purchase of the shares of such companies does not create inconvenience and hardship for the general public. A relaxation in some prohibition is given by the Sharí ${ }^{-}$ah in case of darürah or hājah 'ammmah. Selling and purchasing of shares is not a public need. Ibn Tamiyyah says that relaxation on the grounds of general need is given in case of gharar not in case of riba a, because the evil of gharar is lesser than the evil of riba (Ibn Taymiyyah, 2004). In addition to that, it is also not certain sure that the need for the investor will be fulfilled if he is allowed trading in shares because he may not achieve the purpose for which he has obtained relaxation, i.e. to earn profit.

3- Analysis of Maxim: "Majority deserves to be treated as a whole thing" and the Maxim 
that "Combination of small harām with the permissible majority does not make, the whole harām."

The implication of the Maxim is that the majority part of the business of the company is permissible. Haram , in the form of interest is only a small part. So, because of dominance of halāl part, all businesses will be treated permissible. The scholars of second group say that this principle does not justify subscription of shares and participation in the business. The above principle only allows dealing with a person whose haläl and harām incomes are mixed, while dominant part is haläl. Thus, one can purchase a commodity from such person. But one cannot buy shares of a company whose halāl income is mixed with harām income, because buying shares means participation in a sinful activity (Yusuf, 2005, p. 251).

4- The Maxim: "A thing which is not allowed in the principal part is allowed as a subsidiary part," (Nadawi, p. 589) cannot be used to justify riba based borrowing and lending. riba is prohibited regardless of whether it is only a subsidiary part of transaction or primary part of transaction, or whether it is small in quantity or large. It is like wine whose large quantity and small quantity both are prohibited. The Qur'ān says:

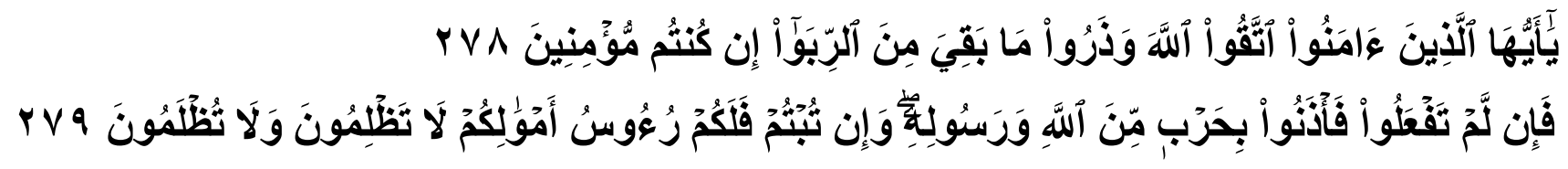

"O ye who believe! Fear Allah, and give up what remains of your demand for usury, if ye are indeed believers. If ye do it not, take notice of war from Allah and His Messenger: But if ye turn back, ye shall have your capital sums: Deal not unjustly, and ye shall not be dealt with unjustly..." (Al-Baqarah, 278-279).

The Holy Prophet (PBUH) said:

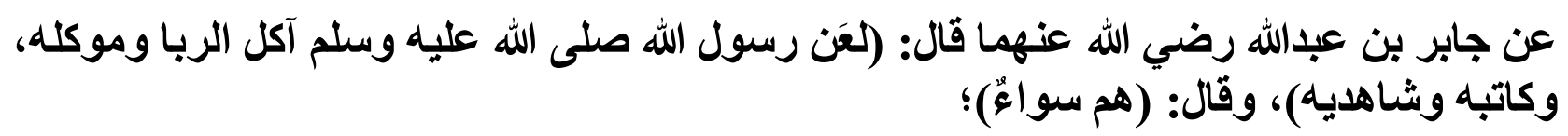

Hazrat Jabir (RA) narrates that; "Holy Prophet (PBUH) cursed the one who takes riba , the one who gives ribā, the one who records it and the two witnesses." He said: "All are equal" (Muslim, hadìth No. 1598)

This goes without saying that the interest which a company receives on its deposits with

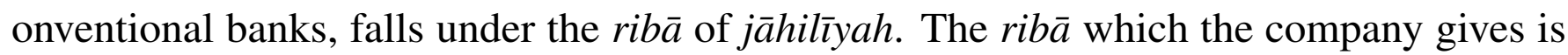
also included in the meanings of the above verses and ahādith. Further, Islam does not differentiate between $r i b \bar{a}$ based lending and ribā based borrowing.

5- Is Shareholder Responsible for Ribā based Borrowing and Lending?

Some Shari'‘ ah scholars hold the view that in joint-stock companies, decisions are made with a majority vote. A minority shareholder cannot be held responsible for the decisions of majority, as long as he has raised his voice against sinful acts of the company. He is not like a partner in a partnership where all the decisions are taken unanimously, who are all equally responsible for the activities of the partnership. It is argued that the individual shareholder has fulfilled his responsibility by registering his protest in the Annual General Meeting (AGM). So, he is not part of ribā taking or riba giving. But, this argument is not correct, because if a shareholder come to know that a company is involved in rib $\bar{a}$, he should 
immediately disinvest his share, and leave the company. This amounts to repentance for him. However, if he continues his investment, he is insisting on sinful acts. Thus, practically, he has not repented.

6- Reliance on the part of a hadīth: "Al-thuluth wa al-thuluth kathīr"

The argument of Sharī'ah scholars of first group is that Holy Prophet (PBUH) in a hadìth has drawn a line of demarcation between kathīr (majority) and qalīl (minority).

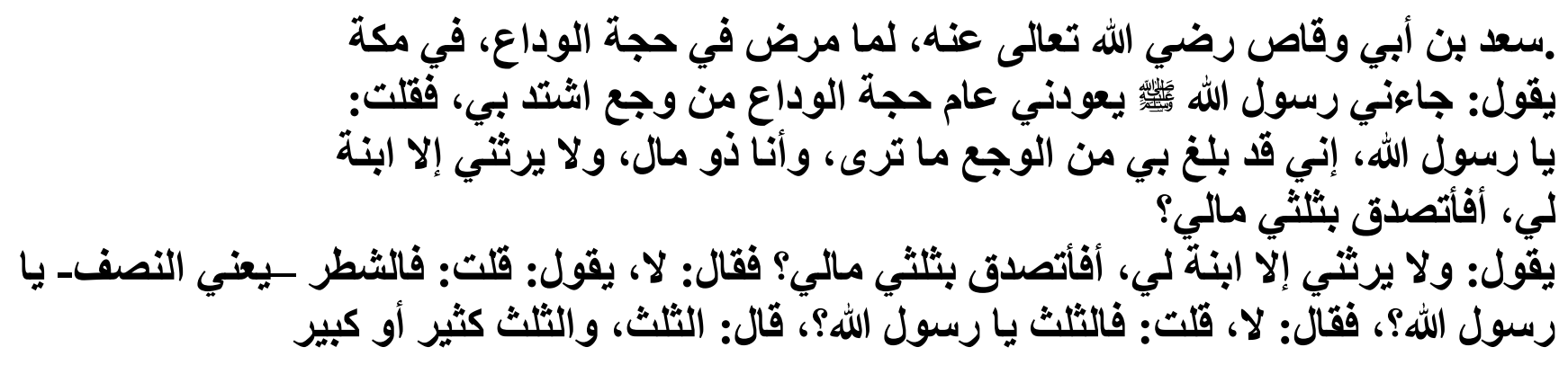

Hazrat Sad bin Abi Waqas said: Holy Prophet (PBUH) visited me in my illness which brought me near death in the year of farewell pilgrimage. I said, Allah's Prophet (PBUH): you can see the pain with which I am suffering. And I am a rich man and there is none to inherit me except only one daughter. Should I give two-thirds of my property as sadaqah? He said: No. Should I give half? He said: No. He further said: Give one third in charity and it is quite enough seeking there with the pleasure of Allah..." (Muslim, 2000).

Reliance on the above hadith and arguments generally given imply that the Sharīah scholars favouring relaxation in interest borrowing and lending, do not have any specific Sharī'ah evidence to support their viewpoint. They only rely on general principles such as hājah 'āmmah (public need) 'umūm balwá (Matter of Common Occurrence), primary and subsidiary part of a thing, and similar other general principles which are not relevant to the real issue of prohibition of interest and the problems created by it for the human being.

\section{Criteria for Liquid and Non-Liquid Assets Ratios}

The criteria require that the ratio of illiquid assets to total assets should be at least $25 \%$. Liquid assets involve cash, debt, and receivables of the company, while illiquid assets comprise inventory of raw material, property, plants and machinery, stock in trade, etc. Under this criterion, the ratio of non-liquid assets viz a viz liquid assets should be significant, and $25 \%$ is considered significant part of combination. In other words, illiquid assets should not be less than $25 \%$ of total assets of the company. The reason for emphasis on illiquid assets is that if all the assets are in form of cash, then they can be traded only at par value because the ahkām of bay al-sarf apply to this case. Thus, a share of 10 rupees can be sold for 10 rupees, neither more nor less. Otherwise, it would involve ribā. But when shares comprise tangible assets, then they can be traded at a price different from its par value or face value. Here the requirement is that tangible assets should not be less than $25 \%$ of total assets. In such case, size of cash, debt and receivable will be ignored because primary object of transaction is trading in the assets of the company. The purpose is not exchange between two

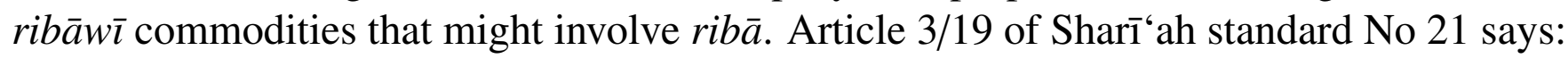

"If the assets of a corporation are composed of tangible assets, benefits, cash and debts, 
the rule for trading in the shares of such a corporation will differ according to the primary asset, which conforms to the objective of the corporation and its usual activity. If its purpose and activity pertain to trading in tangible assets, benefits and rights, trading in its shares is permissible without taking into account the rules of sarf or transactions in debts, with the condition that the total market value of assets benefits and rights should not be less than $30 \%$ of the total assets value of the corporation including all assets, benefits, rights and cash liquidity (the corporations debts, current accounts with others, and bonds it holds which constitute debts) irrespective of their size as in such a case these are secondary. If, however, the objective of the corporation and its usual activity is dealing in gold silver or currencies (sirafah), it is obligatory to undertake to trade in its shares in the light of the rules of șarf."

The Sharī'ah Boards of different Islamic capital market indices have different views on the acceptable limit of liquid and illiquid assets. According to Meezan Index (KMI-30), for a company to be Sharī'ah-compliant, the total illiquid assets of the investee company, should be at least $25 \%$ of the total assets. According to Dow Jones, liquid assets should be less than $33 \%$ of market capitalization. AAOIFI sets an acceptable limit of liquid assets at $30 \%$ of total assets.

The Shari' ${ }^{-}$ah justification for not observing the rules of sarf and dayn in this case, is that here, cash or debt based assets are secondary in the transaction. They are not the principal part of the contract, and not it is the primary objective of transaction. AAOIFI explains the Shari' 'ah basis of this permissibility in the following words:

"The basis for the permissibility of trading in shares or corporations, which include cash assets and debts, without regard for the rules of șarf and dealing in debts, even when such debts are more than one-half, is that in such circumstances such assets are deemed secondary, and in secondary things matters that are not customarily overlooked otherwise are overlooked. If, however, the tangible assets and benefits are less than a third it is not permitted to deal in the shares, benefits by observing the rules of sarf or transactions in debts, because in such a case the assets and benefits are meagre and here debts and cash cannot be deemed secondary to them, and they are the primary objective of the contract, thus, those conditions are to be stipulated for them that would be applied to them if they were desired separately (Accounting and Auditing Organization for Islamic Financial Institutions, 2015).

Thus, the reliance of Shari'ah scholars is on the juristic principle, which provides that a thing (in prohibition) that cannot be tolerated in the primary part of contract, can be tolerated in the secondary part. For example, sale of tree with fruits before ripening is permissible, but sale of fruits without tree before ripening is not permissible because it involves grave uncertainty. It is narrated by Ibn Umar (RA) that: Messenger of Allah (PBUH) forbade sale of fruits till they appear to be ripe, forbidding it, both to the seller and to the buyer (Bukhari, 2000).

The hadith provides that the sale of fruits on trees before they appear to be ripe, is unlawful in Shari' $a$ ah. However, if the sale is affected on the tree, along with such unripe fruits, then such sale is valid to all the Muslim jurists, since the sale is affected on tree, the principal object, not the fruits, the subsidiary object. This ruling is reflected in several Shari'ah 
Maxims, such as:

1- A matter that may not be ignored in independent contracts, may be ignored in subsidiary contracts.fazl

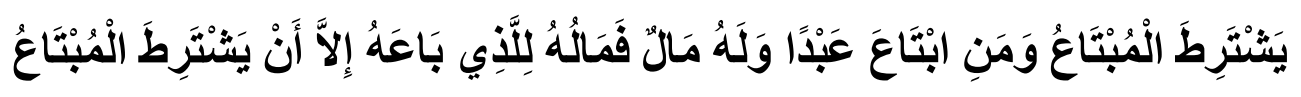

Narrated Abdullah ibn Umar (RA) said, I heard the Messenger of Allah (saws) saying, if somebody buys date-palms after they have been pollinated, the fruits will belong to the seller unless the buyer stipulates the contrary. If somebody buys a slave having some property, the property will belong to the seller unless the buyer stipulates that it should belong to him" (Bukhari, 2000).

Imam Malik says:

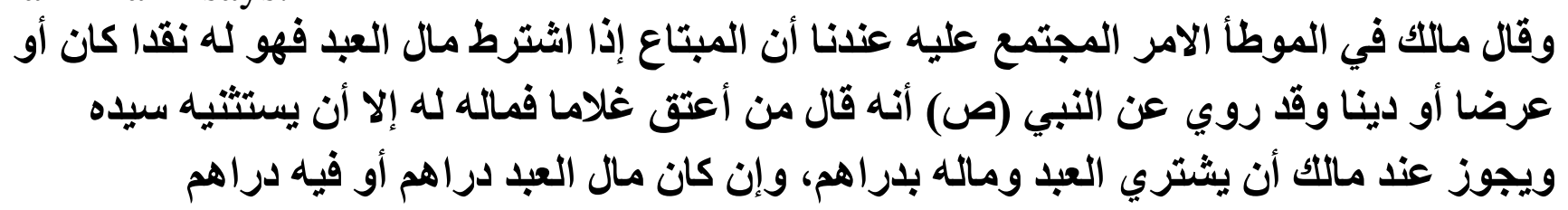

"It is a matter of consensus among us, that if a buyer stipulated for a wealth of slave in the contract, it would be the property of buyer, regardless of whether it is in cash form, or it is some tangible property, or it is receivable. The Holy Prophet (PBUH) said: If a person emancipated a slave, the wealth held by the slave is for him unless the master makes an exception. It is lawful in the opinion of Imam Malik to buy the slave along with his wealth with drähim even if the wealth of the slave is in the form of drähim or it includes a portion of drāhim" (Ibn Rushd, 2014, vol, 2, p. 153).

The statement of Imam Malik (Allah's Blessings be upon him) is explicit, that sarf rules will be ignored in this case, because the gold possessed by the slave, is not the principal object of contract; such sale is permissible, even if the price paid by the buyer, is also in the form of gold. There is yet another ruling in Maliki Law, which suggests that the value of gold content should not be more than one-third of the value of assets i.e., slave in this case. In a statement in Al-Muwatta, Imam Malik rules that if a person bought a sword, or ring, with gold, or silver, content with dinār or dirham, as consideration, such sale would be permissible if the value of gold or silver content is one third, and the value of remaining part is two-third, provided the sale takes place hand to hand, without any delay, in the delivery of counter-values. This is what the people of Madinah have been practicing until our time (Qara Daghi, 2007).

Based on the above opinion, the Sharīaa scholars of different Islamic Capital market indices allow trading of shares composed of liquid and illiquid assets of value other than par value. However, Sh. Muhammad Taqi Usmani has suggested some restrictions in this trading. His opinion is that the price of combination should be more than the value of the liquid amount contained therein. For example, if a share of 10 rupees represents 8 rupees of cash and debt plus some fixed assets worth 2 rupees, the price of the share must be more than 8 rupees. If it is sold for 7 rupees, it will be against the rules of ahkām of riba al-fadl (Usmani, 1996, p. 87).

From this, we may conclude that a stock composed of tangible assets, cash, debt receivable, 
can be traded at a value different from par value. However, illiquid assets should constitute significant part of the combination.

\section{CONCLUSION}

"All Shares Islamic Index" Introduced by SECP in collaboration with Meezan bank is a positive step towards the development of the Islamic Capital market in Pakistan. All shares Islamic Index provides criteria for Sharī'ah screening of companies. It consists of six criteria. The criterion is largely Shari 'ah-compliant. The focus of first criteria is on the lawfulness of the business of Investee Company. The second and third criteria are about interest-based lending and borrowing. According to this criterion a company remains Sharī'ah-compliant if its interest-based lending and borrowing do not cross prescribed limit. A vast majority of Sharī'ah scholars do not consider such companies as Sharī'ah-compliant companies.

It is suggested that rule no 2 (limit on interest based debt taken) and rule no 3 (interest based lending) may be removed from existing screening norms and the investee company should be considered Sharī'ah non-compliant if it involves in riba based dealings regardless of whether the amount or ratio of riba is one percent or 37\%. Needless to say that Shari' 'ah does not makes distinction between small amount of riba or large amount. Criterion no 4 deals with purification by disposing of harām income. The above criterion addresses a situation where a small portion of harām is mixed with a large part of halāl unintentionally and provides a mechanism for purification of illegitimate income arising from that harām part. Criterion no 5 and 6 do not have any Sharī'ah issue based on hadīth of Hazrat Ibn Umar (RA) and the Shar' 'ah maxims, which provide that a thing that may not be ignored in an independent contract can be ignored in subsidiary contracts.

\section{REFERENCES}

Abu Ghuddah, A. S. (2002). Al-Ajwibah al-Sharı`‘ah fi al-Tatbiqat al-Masrafiyyah. Jeddah, Saudi Arabia: Majmuah Dallah al-Barkah.

Accounting and Auditing Organization for Islamic Financial Institutions. (2015). Sharı̄‘ah standards. Retrieved from https://bit.ly/2SF3VUi

Al-Hajjaj, M. B. (2000). Sahih muslim. Al-Riyad, Saudi Arabia: Dar al- Salam.

Al-Umrani, A. I. M. (2006). Al-Istithmar wa al-Mutajarah fi Ashum al-Sharikat alMukhtalatah. Riyad, Saudi Arabia: Kunuz Ashbeliya.

Government of Pakistan \& Securities and Exchange Commission of Pakistan. (2018). Notification. Retrieved from https://bit.ly/2Hj8xtY

Ibn Mani, Abdullah Ibn Sulaiman, Hukm Tadawul ashum al-Sharikat al-Musahimah, bayan wa Shiran

Ibn Rushd. (2014). Bidayat al-mujtahid. Beirut, Lebanon: Dar ul Fikr, Ibn Taymiyyah. (2004). Majmu fatawa. Cairo, Egypt: Dar ar-Rahmat.

Mansoori, M. T., \& Abro, A. H. (2006). Imam Abu Hanifa: Hiyat, fikar aur khidmat. Islamabad, Pakistan: Islamic Research Institute. 
Muslim, S. (2000). Sahih. Riyad, Saudi Arabia: Dar al-Slalam.

Qara Daghi. (2007). Buhuth fi Fiqh al_Buyuk al-Islamiyyah. Beirut, Lebanon: Dar alBashair.

Usmani, M. T. (1996). Islam aour jadid maishat-o-Tijarat. Karachi, Pakistan: Idarat al-Maarif.

Yusuf, A.-S. (2005). Al-Khadmat al-Istithmariyyah fi al-Masarif wa Ahkamuha fi al-Fiqh al-Islami. Karachi, Pakistan: Dar Ibn al-Jouzi.

Zarqa, A. (1983). Sharh al-qawaid al-fiqhiyyah. Demascus, Syria: Dar al-Gharb al-Islami.

$* * * * * * * * * * * * * * * * *$ 